\title{
C-reactive Protein to Albumin Ratio as a Prognostic Predictor in Larynx Cancer
}

\section{Larinks Kanserinde Prognostik Bir Belirteç Olarak C-reaktif Protein Albümin Oranı}

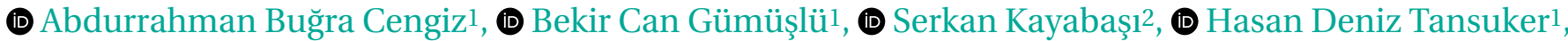 \\ (D) Şahin Öğreden1, (D Mehmet Faruk Oktay1
}

${ }^{1}$ University of Health Sciences Turkey, Bağcllar Training and Research Hospital, Clinic of Otorhinolaryngology, İstanbul, Turkey

${ }^{2}$ Aksaray University Faculty of Medicine, Department of Otorhinolaryngology, Aksaray, Turkey

\section{Abstract}

Objective: During the past decade, several inflammation-based prognostic systems have been reported in the field of clinical oncology. Recently, C-reactive protein and albumin ratio (CAR) have showed their impact on a large variety of tumor types. The aim of this study is to evaluate the impact CAR on prognosis and 5-year survival (5yS) in patients operated for larynx cancer.

Method: One hundred eighteen patients operated in our center between 2010 and 2015 were eligible for retrospective analysis. We evaluated the impact of the CAR and neutrophil to lymphocyte ratio (NLR) on the 5yS. Univariate and multivariate Cox regression analyses were performed to determine the associations of CAR.

Results: The optimal cut-off level of CAR was at 0.993. A low and high CAR was assigned to $40.7 \%$ and $59.3 \%$ of patients, respectively. The $5 y S$ rates of patients with a high CAR were worse than those in the low group $(79.2 \%$ vs $73.2 \% p<0.05)$. Disease stage $(p<0.001)$ and high level of NLR were also significant predictors of 5yS. CAR at diagnosis was associated with an unfavorable progress. Patients with stage III-IV disease had a significantly higher pretreatment CAR than patients with stage I-II disease [respectively $1.83 \pm 0.52$ standard deviation (SD) and $0.58 \pm 0.38$ $(S D), p<0.01]$. ROC analysis of overall survival of larynx squamous cell carcinoma revealed that CAR had a greater area under curve value (0.786) compared to NLR $(0.695)(p<0.01)$.

Conclusion: CAR is an independent prognostic marker in larynx cancer after being adjusted by other accompanying factors and the CAR could be a readily available biomarker in clinical setting.

Keywords: Albumin, C-reactive protein, larynx cancer, prognosis

\section{Öz}

Amaç: Geçtiğimiz on yıl boyunca, klinik onkoloji alanında enflamasyon temelli birkaç prognostik sistem bildirilmiştir. Son zamanlarda, C-reaktif protein ve albümin oranı ( $\mathrm{CAO}$ ), çok çeşitli tümör tipleri üzerinde prognostik belirteç olarak kendini göstermiştir. Bu çalışmanın amacı, larinks kanseri nedeniyle opere edilen hastalarda CAO'nun prognoz ve 5 yıllık sağkalım üzerine etkisini değerlendirmektir.

Yöntem: 2010-2015 yılları arasında merkezimizde ameliyat edilen 118 hasta retrospektif analiz için uygun bulunmuştur. CAO ve nötrofil lenfosit oranın (NLO) 5 yıllık sağkalım üzerindeki etkisi değerlendirildi. CAO ile sağkalım ve prognoz arasındaki ilişkileri belirlemek için tek değişkenli ve çok değişkenli Cox regresyon analizi yapıldı.

Bulgular: CAO'nun optimal cut-off seviyesi 0,993 olarak hesaplandı. Hastaların sırasıyla \%40,7 ve \%59,3'ünde düşük ve yüksek CAO saptandı. Yüksek CAO'lu hastaların 5 yıllık sağkalım oranları düşük gruptakilere göre daha kötü idi $(\% 79,2$ 'ye karşı $\% 73,2, p<0,05)$. Hastalık evresi $(p<0,001)$ ve yüksek NLO değeri de 5 yıllık sağkalım için anlamlı faktörler olarak izlendi. Tanıda CAO kötü prognoz ile ilişkili idi. Evre III-IV hastalığı olan hastalar, evre I-II hastalığı olanlara göre anlamlı olarak daha yüksek bir ameliyat öncesi CAO'ya [sırasıyla 1,83 $\pm 0,52$ standart sapma (SS) ve $0,58 \pm 0,38$ (SS), $p<0,01$ ] sahipti. Gırtlak skuamöz hücreli karsinomun genel sağkalımının ROC analizi, CAO'nun NLO'ya $(0,695)$ kıyasla daha yüksek (eğri altındaki alan) eğri altındaki alan değerine $(0,786)$ sahip olduğunu ortaya koydu $(p<0,01)$.

Sonuç: CAO, eşlik eden diğer faktörlerden bağımsız olarak, larinks kanserinde bir prognostik faktördür ve CAO klinik ortamda kullanıma hazır bir biyobelirteç olabilir.

Anahtar kelimeler: Albümin, C-reaktif protein, larinks kanseri, prognoz

Address for Correspondence: Abdurrahman Buğra Cengiz, University of Health Sciences Turkey, Bağcılar Training and Research Hospital, Clinic of Otorhinolaryngology, İstanbul, Turkey

E-mail: drcengiz@gmail.com ORCID: orcid.org/0000-0003-3942-6765 Received: 17.07.2020 Accepted: 08.09.2020

Cite this article as: Cengiz AB, Gümüşlü BC, Kayabaşı S, Tansuker HD, Öğreden Ş, Oktay MF. C-reactive Protein to Albumin Ratio as a Prognostic Predictor in Larynx Cancer. Bagcilar Med Bull 2020;5(4):179-184

${ }^{\circ}$ Copyright 2020 by the Health Sciences University Turkey, Bagcilar Training and Research Hospital Bagcilar Medical Bulletin published by Galenos Publishing House. 


\section{Introduction}

Larynx cancer is the second most frequent cancer of the upper aerodigestive tract following oral cavity (1). Most of the pathologic diagnoses are squamous cell carcinoma, approximately for $85 \%$ to $95 \%$ of the laryngeal malignant neoplasms (2). In 2019, 12,410 new larynx cancer cases were diagnosed and 3.760 died from this disease. Laryngeal cancer occurs more frequently in men than in women (5.2 cases per 100,000 vs 1.1 per 100,000 , respectively) (3). Approximately $43 \%$ of patients present with advanced (stage III or IV) disease at diagnosis. Unlike other regions, laryngeal cancer is one of a few oncologic diseases in which the 5-year survival rate has decreased over the past 20 years, from $66 \%$ to $60 \%$, although the overall incidence is decreasing (4).

During the past decade, several inflammation-based prognostic systems have been reported in the field of clinical oncology (5). Neutrophil to lymphocyte ratio (NLR), platelet to lymphocyte ratio (PLR), platelet (PLT) and mean platelet volume (MPV) are the most popular ones. Among them, it is well-known that the serum levels of C-reactive protein (CRP) and albumin ratio (CAR) are the most valuable ones (6). CRP is a positive acute-phase protein used for diagnosis in individuals with infection or inflammation and for the evaluation of the effectiveness of the treatment (7). Albumin is a negative acute-phase reactant. Even though albumin decreases mainly in acute inflammation, it is known to be decreased in chronic process of inflammation and it also reflects the nutrition status (8).

Head and neck cancers (HNC) often cause symptoms associated with dysphagia, suggesting that nutrition levels of these patients are generally affected. There are a few studies which have reported the association between the modified Glascow Prognostic score (mGPS) and the prognosis of HNC $(9,10)$. CRP and albumin may separately or together have a prognostic value, either in the short term or in the long term of inflammation. CRP CAR has been reported as an alternative and basic version of GPS as a useful inflammatory index for assessing the status of cachexia (8).

In this retrospective cohort study, we investigated whether the CAR would be as useful as the NLR for predicting the prognosis and the postoperative survival of larynx cancer

\section{Materials and Methods}

A retrospective review was performed using the clinical records of the patients who had undergone elective surgery for Larynx Squamous Cell Carcinoma (LSCC). All the procedures had been performed by the same surgical team at the University of Health Sciences Turkey, Bağcllar Training and Research Hospital, between January 2010 and December 2015. The study protocol and the written informed consent were approved by the Committee of Ethics in Human Research of the University of Health Sciences Turkey, Bağcılar Training and Research Hospital with the approval number 2019.12.2.01.091

\section{Inclusion and Exclusion Criteria}

The inclusion criteria of this study were as follows: 1) being histologically diagnosed as LSCC and operated by our department, 2) having pre-treatment blood sampling for complete blood count (CBC), CRP and albumin measurement, and 3) regular follow-up.

Patients who had any inflammatory, systemic or autoimmune disease and/or malnutritional condition, secondary malignancy and any trauma and medication history that might affect the level of blood parameters were excluded from the study.

\section{Surgery Type}

All cancer patients were assessed with a comprehensive head and neck examination, including flexible direct laryngoscopy and imaging (computerized tomography scans and chest X-rays). Tumors were classified according the TNM classification of the American Joint Committee on Cancer (AJCC) (8 $8^{\text {th }}$ edition, 2017). The patients underwent two types of surgeries according to the stage of the tumor as well as the laryngeal exposure as primary treatment. Endoscopic resection was performed using en-bloc or piecemeal techniques for early stage tumors. Open surgery included partial (laryngofissure cordectomy, supraglottic or supracricoid horizontal laryngectomy) and total laryngectomy, and the minimum follow-up duration of the patients included in the study was 24 months.

\section{Clinical Data Extraction}

We reviewed baseline characteristics of participants, including age, gender, disease stage, smoking status, tumor histology, factors related to the primary treatment (the start and the end of the treatment, treatment regimen, type of surgery, treatment of neck, radiotherapy doses, duration of treatment, interruptions, radiologic (magnetic resonance, positron emission tomography scan) follow-up and 5 years of outcomes and survival rates, the incidence of recurrence and second primary malignancy by using a standard data extraction system. Tumors were classified according to the 
TNM classification of the AJCC (8th edition, 2017). Blood samples were tested prior to the initial treatment. We noted the blood parameters including CBC, CRP and albumin. Then, we calculated CAR and NLR values of the study groups and the control group. Then, we investigated the most sensitive and specific indicator parameter associated with larynx cancer

\section{Statistical Analysis}

The chi-square or Fisher's Exact test was used to compare the categorical variables, which was presented as the numbers and percentages of patients. Univariate analyses were conducted using the log-rank test analysis. Multivariate analysis of these variables in survival was performed using the Cox proportional hazards model. For advanced comparisons of CAR, white blood cells, hemoglobin (Hgb), PLR, and MPV, we used the Mann-Whitney U test, as Post-hoc test. To detect the most significantly associated parameter with the activity of RAS, the receive operating characteristic (ROC) curve analysis was carried out to assess the cut-off of CAR. The optimal cut-off values were identified as the values that maximize the Youden index (sensitivity + specificity - 1). Survival curves were estimated with the Kaplan-Meier method. The associations of CAR with survival were evaluated in univariable and multivariable cox regression models. For statistical analysis of all data, we used SPSS software for Windows (SPSS Inc., Chicago, IL, USA). All tests were two-sided and a p-value $<0.05$ was considered statistically significant.

\section{Results}

One hundred thirty one patients were operated in our tertiary clinic between 2010 and 2015. During the follow-up period, 7 of these patients died from disease independent reasons and 6 patients died in followup. Thus, 118 patients were included in the study. The median follow-up period was 51.2 months (range: 8-60 months). One hundred twelve of the 118 (94.9\%) patients were men, and 6 (5.1\%) were women. The demographic characteristics of the patients are described in Table 1. The median age was 65 years (range: $45-78$ years). Most of them were older than 65 years $(\mathrm{n}=84,71.2 \%)$. The majority of the patients had a disease stage of IV $(40.7 \%)$ and stage III $(28.8 \%) .22 \%$ of the patients were stage I and $8.1 \%$ of the patients were stage II. The distribution of the primary tumor was as follows: glottic $(n=98)$, supraglottic $(n=15)$, and subglottic $(\mathrm{n}=5)$.

Table 1. Clinicopathological characteristics of patients stratified by CAR and NLR (CAR C-reactive protein to albumin ratio, NLR neutrophil to lymphocyte ratio)

\begin{tabular}{|c|c|c|c|c|c|c|c|}
\hline & $n=118$ & $\%$ & $\begin{array}{l}\text { CAR } \\
\text { Mean } \pm \text { SD }\end{array}$ & $\begin{array}{l}\text { NLR } \\
\text { Mean } \pm \text { SD }\end{array}$ & $\begin{array}{l}\mathrm{Hb} \\
\text { Mean } \pm \text { SD }\end{array}$ & $\begin{array}{l}\mathbf{p} \\
\text { CAR }\end{array}$ & $\begin{array}{l}p \\
\text { NLR }\end{array}$ \\
\hline Gender & & & & & & 0.659 & 0.762 \\
\hline Male & 112 & 94.9 & $1.81 \pm 0.98$ & $3.01 \pm 0.89$ & $13.83 \pm 0.69$ & - & - \\
\hline Female & 6 & 5.1 & $1.84 \pm 0.42$ & $3.04 \pm 0.96$ & $14.41 \pm 0.51$ & - & - \\
\hline Age & & & & & & 0.637 & 0.654 \\
\hline$<65$ years & 84 & 71.2 & $1.81 \pm 0.44$ & $2.99 \pm 0.95$ & $13.92 \pm 0.73$ & - & - \\
\hline$>65$ years & 34 & 28.8 & $1.94 \pm 0.05$ & $3.07 \pm 0.76$ & $13.70 \pm 0.58$ & - & - \\
\hline Localization & & & & & & 0.092 & 0.08 \\
\hline Glottic & 98 & 83.1 & $1.85 \pm 0.21$ & $3.04 \pm 0.94$ & $13.86 \pm 0.72$ & - & - \\
\hline Supraglottic & 15 & 12.7 & $1.80 \pm 0.11$ & $2.82 \pm 0.55$ & $13.78 \pm 0.44$ & - & - \\
\hline Subglottic & 5 & 4.2 & $1.54 \pm 0.18$ & $2.98 \pm 0.83$ & $14.01 \pm 0.83$ & - & - \\
\hline Stage & & & & & & $<0.01$ & 0.567 \\
\hline I & 10 & 8.5 & $0.36 \pm 0.46$ & $2.89 \pm 0.78$ & $13.96 \pm 0.59$ & - & - \\
\hline II & 26 & 22 & $0.63 \pm 0.45$ & $3.14 \pm 0.93$ & $14.02 \pm 0.66$ & - & - \\
\hline III & 34 & 28.8 & $1.65 \pm 0.59$ & $2.88 \pm 0.67$ & $13.72 \pm 0.55$ & - & - \\
\hline IV & 48 & 40.7 & $2.01 \pm 0.56$ & $3.05 \pm 1.03$ & $13.85 \pm 0.81$ & - & - \\
\hline Lymph node metastasis & & & & & & 0.045 & 0.07 \\
\hline Yes & 47 & 39.9 & $1.85 \pm 0.44$ & $3.02 \pm 0.16$ & $13.92 \pm 0.73$ & - & - \\
\hline No & 71 & 60.1 & $1.77 \pm 0.05$ & $2.99 \pm 0.91$ & $13.70 \pm 0.58$ & - & - \\
\hline Total & 118 & 100 & $1.82+0.86$ & $3.01 \pm 0.89$ & $13.86 \pm 0.69$ & - & - \\
\hline
\end{tabular}

SD: Standard deviation, CAR: C-reactive protein to albumin ratio, NLR: Neutrophil to lymphocyte ratio, Hb: Hemoglobin 
Local recurrences occurred in 20 patients (16.9\%) and locoregional recurrences developed in 47 (39.9\%) patients. Twenty eight (23.7\%) patients died due to disease in the five years. The 5 -year overall survival (OS) rate for the entire cohort was $76.3 \%$. Using the roc chart, we found that the range of cut-off value for CAR was 0.993 as the optimal cut-off level for assessing 5-year survival (Figure 1). Patients were divided into two groups based on the cut-off value of CAR $\geq 0.993(n=70,59.3 \%)$ and CAR $<0.993(\mathrm{n}=48,40.7 \%)$. Using the same technique, we found that the range of cut-off value for NLR was 3.05 as the optimal cut-off level for assessing 5 -year survival (Figure 2). Patients were divided into two groups based on the

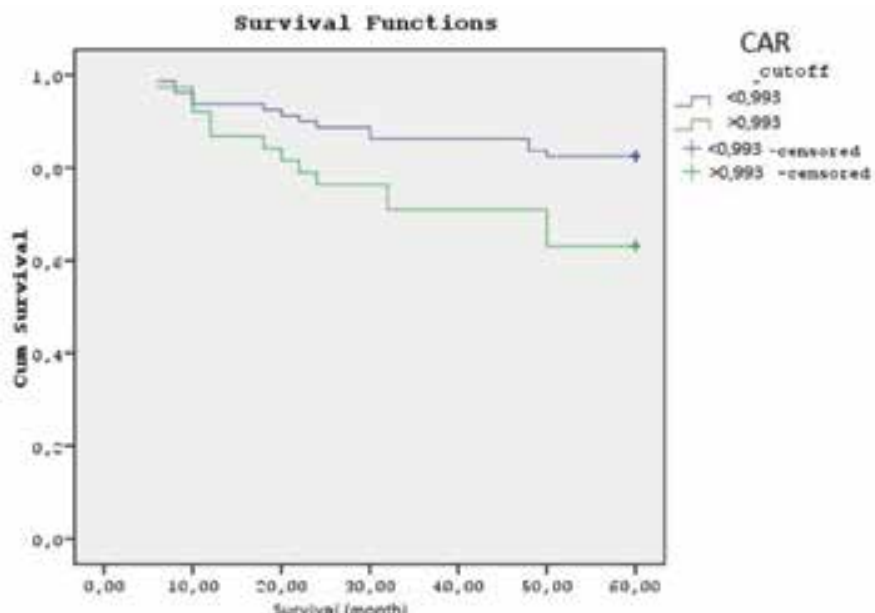

Figure 1. Kaplan-Meier curves for overall survival according to CAR at diagnosis. OS stratified by CAR at diagnosis (CAR <0.99 vs CAR $\geq 0.99$ )

CAR: C-reaction protein to albumin ratio, OS: Overall survival

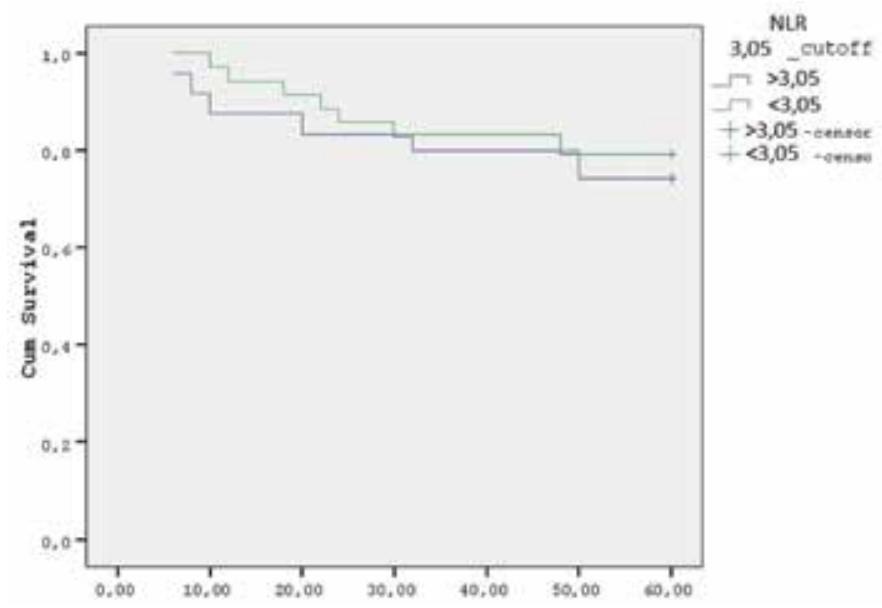

Figure 2. Kaplan-Meier curves for overall survival according to NLR at diagnosis. OS stratified by CAR at diagnosis (NLR $<3.05$ vs NLR $\geq 3.05$ )

NLR: Neutrophil to lymphocyte ratio, OS: Overall survival, CAR: C-reaction protein to albumin ratio cut-off value of NLR $\geq 3.05$ ( $\mathrm{n}=38,32.2 \%$ ) and NLR $<3.05$ $(\mathrm{n}=80,67.8 \%)$.

In contrast to the patients with high CAR, patients with low CAR had longer 5 -year survival $(74.3 \%$ vs $79.2 \%$, $\mathrm{p}<0.05$ ) (Figure 1). Similarly, longer 5-year survival was also significantly observed in patients with low NLR compared to high NLR ( $73.2 \%$ vs $79.5 \%$, p $<0.05$ ). Figure 3 represents the graph of the ROC analysis of the parameters including CAR and NLR. ROC analysis of OS of LSCC revealed that CAR had a greater area under curve (AUC) value (0.786) compared to NLR $(0.695)(\mathrm{p}<0.001)$.

According to stage, patients with stage III-IV disease had a significantly higher pretreatment CAR $(1.83 \pm 0.52)$ than patients with stage I-II disease $(0.58 \pm 0.38, \mathrm{p}<0.01)$ (Table 1). Similarly, in terms of lymphatic metastasis, positive patients had a significantly higher pretreatment CAR (1.85 \pm 0.44$)$ than patients with negative lymphatic metastatic disease $(1.77 \pm 0.05, \mathrm{p}=0.045)$ (Table 1$)$. However, there was no significant association between CAR-NLR and gender ( $\mathrm{p}=0.077)$, age $(\mathrm{p}=0.087)$ and localization of tumor. Moreover, CAR was identified as a significant prognostic factor for the OS when adjusted by clinicopathological factors, other inflammation based factors and other tumor markers (adjusted hazard ratio 2.13, 95\% confidence interval 1.38-3.4, $\mathrm{p}=0.002$ ).

\section{Discussion}

There are numerous factors that contribute to the prognosis of laryngeal cancers such as location of tumor, age, gender,

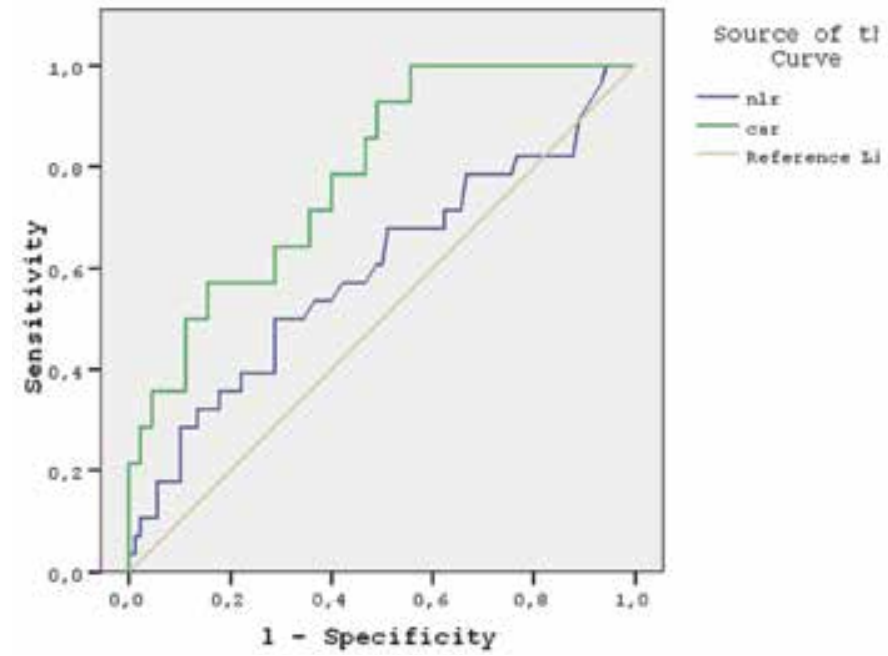

Figure 3. The graph of the ROC analysis of the parameters including CAR and NLR

NLR: Neutrophil to lymphocyte ratio, CAR: C-reaction protein to albumin ratio, ROC: Receive operating characteristic 
alcohol, cigarette usage, histology, histological grade, anterior commissure involvement, performance status, Hgb level and duration of primary treatment (11). LSCC patients are at the highest risk for recurrence in the first three years following the treatment. After this, the chance of recurrence is low, and any lesion represents a new primary cancer (12).

Intheliterature, thelinkbetweencancerandinflammation has been evaluated previously (13). Several potential mechanisms have been suggested for the relationship between inflammatory response and cancer (14). Tumor growth or invasion could activate tissue inflammation and then tumor overgrowth induces hypoxic necrosis and local tissue damage, this is also thought to activate an inflammatory response. And the other hypothesis is that cancer cells and associated leukocytes could trigger the production of the inflammatory cytokines and chemokines which facilitate cancer growth, invasion and angiogenesis, such as tumor necrosis factor, vascular endothelial growth factor interleukin (IL)-1, -6, and -8. As a result, disruption of the host immune response and resistance to cytotoxic drugs might occur (15). The CRP concentration has been found to be useful in evaluating both the severity of inflammation and treatment method in cases of respiratory tract inflammation and myocardial infarction $(16,17)$. Determination of CRP is a cheap, consistent and reproducible test and is available in almost every hospital.

There is an increasing interest in the use of blood parameters as prognostic factors in cancers. Neutrophil, lymphocyte, CRP and PLT counts, either as individual values or in relation to each other, could be associated with the cancer prognosis (17-20). NLR and the CAR were reported to have a significantly prognostic value as the markers of inflammation $(5,18,19)$. NLR, a novel potential marker for identifying inflammation in various diseases, is a valuable marker, easily accessible and cheap parameter unlike the expensive inflammatory markers such as IL-6, IL-1b. Ozyalvacli et al. (20) have reported that high NLR is a significant diagnostic factor of distinction of breast cancer. NLR is also found to be an important prognostic marker for stage II or III gastric cancer associated with poor prognosis (21).

CRP is an acute-phase reactant synthesized by hepatocytes, which is regulated by proinflammatory cytokines, particularly IL-6 (22). In patients with cancer, there is evidence of the stereotyped acute-phase protein reply of increased CRP and decreased albumin, and this relationship is similar to different tumor types (23).
Several studies have investigated the association between inflammatory mediators and HNC. Nakayama et al. (9) reported for the first time the clinical value of the mGPS in patients with HNC. In a different study, the relationship between inflammatory indices, including the CRP and albumin levels, and the disease prognosis showed salivary duct carcinoma (24). Kinoshita et al. (15) have demonstrated that the CAR is an independent prognostic marker in patients with hepatocellular carcinoma. Similar to this finding, after the analysis of 1.572 patients who were treated for nasopharynx carcinoma (NPC), Zhang et al. (25) reported that CAR might be an useful prognostic indicator in patients with NPC, independent of disease stage. According to the literature, it can be said that the CAR would be applicable as a new inflammation-based prognostic system that could add a new aspect to prognostication and classification potential.

We found that patients with an elevated CAR were more likely to be LSCC with high stage tumor. Moreover, the multivariate analysis demonstrated that patients who had advanced stage disease and CAR higher than 0.99 had more possibility of locoregional recurrence and poor survival rates than patients with low CAR levels. This may also lead to poor prognosis in patients with high CAR. When compared to NLR, higher NLR might also be an indicator of poor prognosis in patients with LSCC, but CAR had a greater AUC in the ROC analysis. According to these results, CAR appears to be more valuable than NLR for predicting the outcome of the surgery and prognosis in survival in larynx malignancy.

\section{Study Limitations}

The primary limitation of the study was its retrospective design since it included only a limited number of parameters obtained from the medical data of the patients. Nevertheless, this study may provide an inspiration for further prospective investigations of many other blood test parameters associated with inflammation in patients with larynx cancer.

\section{Conclusion}

In this study, we retrospectively analyzed the utility of CAR in 118 eligible patients with LSCC in our cancer center. To our knowledge, this is the first study to analyze the correlation between CAR and prognosis in patients with LSCC. The results of this study demonstrated that high CAR was independently associated with poor prognosis in patients with LSCC as well as advanced stage and high NLR at the time of diagnosis. 


\section{Ethics}

Ethics Committee Approval: All procedures performed in studies were in accordance with the ethical standards of Committee in University of Health Sciences Turkey, Bağcllar Training and Research Hospital with number and date 2019.12.2.01.091/27.12.2019.

Informed Consent: A consent form from each patient was taken.

Peer-review: Externally peer-reviewed.

\section{Authorship Contributions}

Concept: A.B.C., S.K., Design: Ş.Ö., B.C.G., Data Collection or Processing: B.C.G., H.D.T., Analysis or Interpretation: A.B.C., S.K., Literature Search: M.F.O., Ş.Ö., Writing: A.B.C., B.C.G.

Conflict of Interest: No conflict of interest was declared by the authors.

Financial Disclosure: The authors declared that this study has received no financial support.

\section{References}

1. Jemal A, Siegel R, Ward E, Murray T, Xu J, Thun MJ. Cancer statistics, 2007. CA Cancer J Clin 2007;57(1):43-66.

2. Megwalu UC, Sikora AG. Survival outcomes in advanced laryngeal cancer. JAMA Otolaryngol Head Neck Surg 2014;140(9):855-860.

3. Siegel RL, Miller KD, Jemal A. Cancer statistics, 2019. CA Cancer J Clin 2019;69(1):7-34.

4. Zuniga SA, Lango MN. Effect of rural and urban geography on larynx cancer incidence and survival. Laryngoscope 2018;128(8):18741880.

5. Cayir S, Hizli O, Kayabasi S. Is C-reactive protein to albumin ratio an indicator of poor prognosis in Bell's palsy? Eur Arch Otorhinolaryngol 2020;277(1):115-119.

6. McMillan DC. The systemic inflammation-based Glasgow Prognostic Score: a decade of experience in patients with cancer. Cancer Treat Rev 2013;39(5):534-540.

7. Póvoa P, Coelho L, Almeida E, Fernandes A, Mealha R, Moreira $\mathrm{P}$, et al. Pilot study evaluating C-reactive protein levels in the assessment of response to treatment of severe bloodstream infection. Clin Infect Dis 2005;40(12):1855-1857.

8. Don BR, Kaysen G. Serum albumin: relationship to inflammation and nutrition. Semin Dial 2004;17(6):432-437.

9. Nakayama M, Tabuchi K, Hara A. Clinical utility of the modified Glasgow prognostic score in patients with advanced head and neck cancer. Head Neck 2015;37(12):1745-1749.

10. Hanai N, Sawabe M, Kimura T, Suzuki H, Ozawa T, Hirakawa H, et al. The high-sensitivity modified Glasgow prognostic score is superior to the modified Glasgow prognostic score as a prognostic predictor for head and neck cancer. Oncotarget 2018;9(97):3700837016.
11. van der Voet JC, Keus RB, Hart AA, Hilgers FJ, Bartelink H. The impact of treatment time and smoking on local control and complications in T1 glottic cancer. Int J Radiat Oncol Biol Phys 1998;42(2):247-255.

12. Adeel M, Faisal M, Rashid A, Rasheed S, Hussain R, Malik KI, et al. Outcomes of definitive radiotherapy for early laryngeal cancer in terms of survival and patterns of failure. J Laryngol Otol 2019;133(12):1087-1091.

13. Balkwill F, Mantovani A. Inflammation and cancer: back to Virchow? Lancet 2001;357(9255):539-545.

14. Mantovani A, Allavena P, Sica A, Balkwill F. Cancer-related inflammation. Nature 2008;454(7203):436-444.

15. Kinoshita A, Onoda H, Imai N, Iwaku A, Oishi M, Tanaka K, et al. The C-reactive protein/albumin ratio, a novel inflammationbased prognostic score, predicts outcomes in patients with hepatocellular carcinoma. Ann Surg Oncol 2015;22(3):803-810.

16. Brescia G, Marioni G, Franchella S, Ramacciotti G, Giacomelli L, Marino F, et al. A prospective investigation of predictive parameters for post-surgical recurrences in sinonasal polyposis. Eur Arch Otorhinolaryngol 2016;273(3):655-660.

17. Ridker PM, Hennekens $\mathrm{CH}$, Buring JE, Rifai N. C-reactive protein and other markers of inflammation in the prediction of cardiovascular disease in women. N Engl J Med 2000;342(12):836843.

18. Lin GN, Peng JW, Liu PP, Liu DY, Xiao JJ, Chen XQ. Elevated neutrophil-to-lymphocyte ratio predicts poor outcome in patients with advanced non-small-cell lung cancer receiving first-line gefitinib or erlotinib treatment. Asia Pac J Clin Oncol 2017;13(5):e189-e194.

19. Fairclough E, Cairns E, Hamilton J, Kelly C. Evaluation of a modified early warning system for acute medical admissions and comparison with C-reactive protein/albumin ratio as a predictor of patient outcome. Clin Med (Lond) 2009;9(1):30-33.

20. Ozyalvacli G, YesilC, Kargi E, Kizildag B, Kilitci A, YilmazF. Diagnostic and prognostic importance of the neutrophil lymphocyte ratio in breast cancer. Asian Pac J Cancer Prev 2014;15(23):10363-10366.

21. Mori M, Shuto K, Kosugi C, Narushima K, Hayashi H, Matsubara $\mathrm{H}$, et al. An increase in the neutrophil-to-lymphocyte ratio during adjuvant chemotherapy indicates a poor prognosis in patients with stage II or III gastric cancer. BMC Cancer 2018;18(1):1261.

22. Roxburgh CS, McMillan DC. Cancer and systemic inflammation: treat the tumour and treat the host. Br J Cancer 2014;110(6):14091412 .

23. McMillan DC. An inflammation-based prognostic score and its role in the nutrition-based management of patients with cancer. Proc Nutr Soc 2008;67(3):257-262.

24. Kawakita D, Tada Y, Imanishi Y, Beppu S, Tsukahara K, Kano S, et al. Impact of hematological inflammatory markers on clinical outcome in patients with salivary duct carcinoma: a multiinstitutional study in Japan. Oncotarget 2017;8(1):1083-1091.

25. Zhang Y, Zhou GQ, Liu X, Chen L, Li WF, Tang LL, et al. Exploration and Validation of C-Reactive Protein/Albumin Ratio as a Novel Inflammation-Based Prognostic Marker in Nasopharyngeal Carcinoma. J Cancer 2016;7(11):1406-1412. 